\title{
Residuos de antibióticos en la leche comercializada en Brasil: una revisión de los estudios publicados en los últimos años
}

\author{
Antibiotic residues in Brazilian milk: \\ a review of studies published \\ in recent years
}

\begin{abstract}
Antibiotics are widely used for the treatment of dairy cows and the residues of these drugs may remain in milk and dairy products, which can be a potential threat to human health. Exposure to low levels of antibiotics is considered a public health problem as this may result in the development of resistant strains of human bacteria. The presence of antibiotic residues (AR) in milk is also a problem for the dairy industry as they can inhibit the growth of lactic bacteria. According to Brazilian legislation, antimicrobials should be used in accordance with Good Farming Practices. However, recent studies have reported contamination in milk marketed in the country. This work aimed to review studies, published over the last 10 years, which describe $A R$ in milk marketed in Brazil. The Maximum Residue Limit, the methods for quantification of $A R$ and the results of published studies by authors and government agencies are discussed.

Key words: Antimicrobials, maximum residue limit, food safety, milk quality.
\end{abstract}

Felipe M. Trombete (1) Regiane R. dos Santos (1)

André L. R. Souza (2)

(1) Department of Food Technology (DTA) Universidade Federal Rural do Rio de Janeiro/UFRRJ, Brazil (2) Institute of Chemistry, Federal University of Rio de Janeiro (UFRJ), Brazil.

Dirigir la correspondencia a: Felipe M Trombete
Departamento de Tecnología de Alimentos, PPGCTA Rodovia BR 465, km 7, UFRRI, Seropédica-RJ, 23890-000 Brasil.

E-mail: trombete@ufrrj.br

Este trabajo fue recibido el 30 de Octubre de 2013 y aceptado para ser publicado el 28 de Marzo de 2014.

\section{INTRODUCTION}

Brazil is one of the largest milk producers, and ranks fifth in the world, with a production around 32,000 ton of milk per year (1).

The quality of milk is a subject of worldwide importance because it is a food of high nutritional value and is consumed by all populations, from newborns to the elderly. Thus milk and milk products intended for human consumption must be safe, without microbiological, physical or chemical contaminants (2).

Among the main contaminates of milk are toxic metals, mycotoxins, radionuclides, pesticide and veterinary drug residues $(3,4)$.

Antibiotic contamination in milk occurs due to the misuse and/or fraudulent use of veterinary drugs in dairy cows. The milk obtained from animals still undergoing treatment must be discarded, and under no circumstances can it be used for consumption before the withdrawal period specific for each drug is reached (5).

Strict sanitary controls, including adequate feeding and good farming and production practices must be carried out on dairy farms, in order to reduce or even dispense with the use of these drugs (6). However, when the use is necessary, it is important to comply with the guidelines from the national supervisory bodies regarding their use for animals in lactation (7).

Several countries have stipulated Maximum Residue Limits (MRL) for the presence of different classes of antibiotics in milk, such as Beta-lactams, tetracyclines, sulfonamides, quinolones, aminoglycosides and chloramphenicol (8).

According to Brazilian legislation, antimicrobials should be used only when needed and in accordance with the Good Farming Practices. However, recent studies have reported AR contamination in milk marketed in Brazil (9-11).

This fact represents a serious public health problem because the presence of these contaminants above the MRL may trigger allergic processes, vomit, diarrhea, kidney problems, anemia and antimicrobial resistance (AMR), effects that are exacerbated in pregnant women, children and the elderly (12).

AMR refers to the capacity of microorganisms to resist antimicrobial treatments. The inappropriate use of antibiotics has been linked to the emergence and spread of microorganisms which are resistant to these antibiotics, rendering treatment of human diseases ineffective and posing a serious risk to public health $(12,13)$.

In the European Union, about 25.000 deaths per year 
are caused by resistant bacteria. Incorrect use of antibiotics in animals is considered one of the major causes of this resistance (14).

Another significant problem caused by the presence of antimicrobial residues in milk is undesirable effects on the production of dairy products. These residues can influence the quality of products by inhibiting fermentation by lactic acid bacteria in the production of yogurt, cheese and butter, causing serious economic problems for the dairy industry (15).

This work aimed to review studies published over the last 10 years about the occurrence of AR in milk marketed and consumed in Brazil. The" Maximum Residue Limit" prevailing in the country, the most commonly used methods for identification and quantification in milk and the results of published studies by authors and government agencies in recent years are discussed.

\section{HAZARDS OF MILK CONTAMINATED WITH \\ ANTIBIOTIC RESIDUES FOR HUMAN HEALTH AND IMPLICATIONS ON THE DAIRY INDUSTRY}

Milk means the product from complete and uninterrupted hygienic milking of healthy, well fed and rested cows (16).

Milk and milk products are a rich and convenient source of nutrients for people in many countries and there is a significant international trade of milk-based commodities. It is an important component of a balanced diet, and is considered one of the world's most complete foods and a rich source of proteins, vitamins and minerals, such as calcium, magnesium, phosphorus, potassium and zinc (17).

Normally when some disease is detected in dairy cows, particularly mastitis, regular doses of antimicrobials are given during the treatment. Antimicrobials, such as antibiotics, are substances used to kill micro-organisms or to stop them from growing and multiplying. They are commonly used in veterinary medicine to treat a wide variety of infectious diseases (14).

The Codex Alimentarius recommends that when dairy cows are treated with antibiotics, their milk should be discarded until the withdrawal period specified for each veterinary drug being used is reached; this can be days or even weeks (17).

The use of contaminated milk with antimicrobial residues is illegal and when intended of dairy products may interfere in the fermentation processes and, consequently, on the technological properties of the final products, causing economic losses to the industry.

When destined for human consumption it can cause severe allergic reactions, toxic and carcinogenic effects and induce bacterial resistance. A well known example of an bacterium that infects animals and humans and has acquired resistance to multiple antibiotics is Methicillin-resistant Staphylococcus aureus - MRSA $(12,13)$.

MRSA is considered to be a global public health problem that involves medical health care, veterinary medicine, agriculture and environment. Several recent studies have reported on the problems caused by consumption of contaminated milk and $A M R$ in humans $(12,13)$.

The dairy farmer's lack of knowledge concerning the negative effects of these drugs on human health contributes to aggravate such problems $(18,19)$.

However, it should be noted that not all antibiotics or other veterinary drugs used for animals confer risk to human health. What must be considered is the "Maximum Residue Limit", which is defined, by the authorities, as the maximum concentration (in $\mu$ g.L-1) of antibiotic residues in milk that bears no sanitary hazard for the consumer and has no negative effect on production processes. It is usually based on the Acceptable Daily Intake (ADI) for the consumer that is calculated from the NOEL (No Observable Effect Level) and a safety factor considering the toxicity, teratogenicity, mutagenicity, carcinogenicity and sensitizing potential for allergic reactions (immunotoxicity) of the substance (20).

The authorities consider there is no health hazard for the consumer and no effect on production processes below the MRL. The MRL for antibiotic residues in Brazilian milk is established by the Ministry of Health, using the Mercosul MRL as reference (21).

Table 1 shows the MRL for the main veterinary drugs permitted for the treatment of diseases in dairy cattle in Brazil.

These limits were established in 2002 by the Ministry of Agriculture, Livestock and Food Supply (MAPA). When the substance registered for the specie in question has no MRL

Maximum Residue Limit for certain antibiotics in Brazilian milk.

\begin{tabular}{|c|c|c|c|}
\hline Antibiotic & $M R L\left(\mu g . L^{-1}\right)$ & Antibiotic & $M R L\left(\mu g . L^{-1}\right)$ \\
\hline Chlortetracycline & & Flumequine & 50 \\
\hline Oxytetracycline & & Ceftiofur & 100 \\
\hline Tetracycline & & Cloxacillin & 30 \\
\hline Doxycycline & & Dicloxacillin & 30 \\
\hline Sulfathiazole & & Ampicillin & 4 \\
\hline Sulfamethazine & 100 & Amoxicillin & 4 \\
\hline Sulfadimethoxine & & Oxacillin & 30 \\
\hline Sulfadiazine & & Penicillin G & 4 \\
\hline Sulfadoxine & & Penicillin V & 4 \\
\hline Sulfamiderazin & & Ciprofloxacin & 100 \\
\hline Sulfamethoxazole & & Enrofloxacin & 100 \\
\hline Sulphaquinoxaline & & Chloramphenicol & 0.30 \\
\hline
\end{tabular}


established, this value is equal $10 \mu \mathrm{g} . \mathrm{kg}-1$ ou $10 \mu \mathrm{g} . \mathrm{L}-1$ (22).

The limits established by Brazilian legislation are similar to those set by the European Commission and can be considered adequate for public protection against AR contamination in milk (20).

As can be seen in table 1, the MRL for antibiotics in milk has concentrations of parts per billion ( $p p b$ or $\mu g . L-1$ ), thus to determine the presence and quantifying the levels of these AR highly sensitive analytical methods are needed which must also be quick and convenient, are necessary.

\section{METHODS OF IDENTIFICATION AND QUANTIFICATION}

In Brazil, the control of residues and contaminants in milk is carried out by the Ministry of Agriculture, Livestock, and Supply - MAPA, through "The National Plan for Control of Residues and Contaminants" - PNCRC. This program aims to continuously assess samples of food products in general sold in the country.

The official methods of identification and quantification of AR used by the national reference laboratories are High Performance Liquid Chromatography with fluorescence detection (HPLC-FLD), HPLC coupled to mass spectrometry (HPLC-MS or HPLC-MS/MS) and the screening techniques based on immunoenzymatic reactions and microbial inhibition (8), as described below.

Methods based on microbial inhibition

Methods based on microbial inhibition are most commonly used for the qualitative evaluation of the AR in milk because they are fast and the results are obtained in hours; practical and a large numbers of samples can be analyzed simultaneously; and they are sensitive to different classes of antibiotics (23-25).

Among these methods, the most common are based on the inhibition of Bacillus stearothermophilus, in the presence of a $\mathrm{pH}$ indicator. If there is no AR in milk, the bacteria grows and increases the acidity of the medium, changing its color.

Other microorganisms can also be used for this purpose. Biacchi et al (26) used the inhibition method with Escherichia coli and Staphylococcus spp, and obtained results after 18 hours of incubation.

The sensitivity of these methods must be below the MRL established by national legislation so that any contaminated sample near these levels can be detected (5).

Positive samples can be confirmed using more specific methods. The methods described here are used in industry, when large amounts of milk need to be evaluated in a short time.

\section{Immunoenzymatic tests}

Immunoenzymatic assays as well as methods of inhibiting antimicrobials are also widely used by the dairy industry. They are sensitive to different groups of antimicrobials and the results are obtained in a few hours (5).

The principle of this method is based on the binding of antibiotics in milk with proteins conjugated to specific receptors fixed to a plastic unit, indicated by a color change in the reaction medium. It is a qualitative method that is considered more sensitive, faster and more specific than the microbial inhibition tests $(9,10)$

To apply this method, as in microbial inhibition, the analyst must have a basic training and it does not require expensive equipment or specific installations in the industry.
Araújo (27) and Gomes (28) evaluated the effectiveness of several immunoenzymatic kits for the detection of different groups of AR in milk. They concluded that all the kits evaluated were suitable for this purpose and can be used as screening methods for monitoring substances in milk. However, the use of a positive and negative control and the exact temperature during the entire analysis are important points to obtain reliable results.

Gomes (28) observed that the acidity of the milk is also a critical point in these analyses because it can interfere in the results indicating false-positives. Therefore, it is very important to collect and store the samples under refrigeration until the moment of the test.

Folly et al (29) evaluated the efficiency of methodologies based on microbial inhibition, immunoenzymatic reaction and HPLC with a diode array detector for cloxacillin detection in milk. All methods identified the presence of the antibiotic; however, the advantage of using a chromatographic method is the possibility of identifying and quantifying the exact value of the antibiotic in the milk.

\section{Chromatographic methods}

In contrast to the previous methods mentioned above, the determination of AR in milk by chromatography is able to identify and quantify each antibiotic separately. These methods are more sensitive, precise and accurate, and therefore more reliable.

Simple techniques based on Thin Layer Chromatography (TLC) can be used for this purpose, with the advantage of being simple and having direct detection by the chromatographic profile obtained on the plate. This technique can be used for screening tests or direct quantification.

However, HPLC is considered more suitable to quantify with precision, sensitivity and accuracy the levels of AR in milk. Currently, several methodologies have been optimized and validated with this objective.

HPLC with reverse phase column, especially the C18 and Ultra Violet (HPLC-UV), diode array (HPLC-DAD) and fluorescence detector (HPLC-FLD) have been used to determine of a large number of antibiotics in milk samples, such as tetracycline, penicillin, ampicillin, sulfonamides and others (30-35).

HPLC can be coupled to a mass spectrometry system (HPLC-MS or HPLC-MS/MS), with excellent results to determine AR. After chromatographic separation the MS detects the antibiotic through its molecular weight thereby eliminating the necessity of a clean-up of the samples, and thus reducing the overall time of analysis.

The techniques based on HPLC-MS/MS fragment the molecule after their identification, generating a specific spectrum for each substance, which acts as a fingerprint for the AR, consequently, it is even more specific and reliable.

Thus, the main advantages of using HPLC methodologies are the absence of false-positive results and higher specificity of the analysis. However, to implement this methodology expensive equipment, specialized technicians, adequate facilities, equipment maintenance and frequent use of large volumes of solvents are needed.

\section{Methods based on QuEChERS}

The QuEChERS method (Quick, Easy, Cheap, Effective, Rugged and Safe) is considered very promising to determine AR in milk and has been studied by various researchers. QuEChERS was initially developed to examine pesticides in vegetables, proposed by Anastassiades et al (36). It is a 
quick and easy method of extraction, economical because it uses a reduced amount of low toxic solvents and produces reliable results.

Since the advent of QuEChERS, many methods to determine residues and contaminants in food have been validated, including mycotoxins in food (37), pesticides in fruits (38), and veterinary drug residues in meat (39), among others.

Quantification after chromatographic separation is usually performed by FLD detection, UV, DAD or MS. HPLC or GC with MS/MS is the most common technique.

Recent research has been carried out in Brazil in order to validate simple techniques based on QuEChERS to determine AR in milk, demonstrating good analytical results and several advantages over conventional methods $(40,41)$.

When using these analytical methods to quantify AR in milk, mainly the techniques based on HPLC, GC, and MS, continuous validation is extremely important in order to have good analytical quality.

Thus, the main validation parameters considered are repeatability and reproducibility, recovery, limits of detection and quantification and specificity. The reference values for these parameters are determined by research bodies and their studies evaluate the suitability of the method for the purpose for which it was designed $(42,43)$.

\section{OCCURRENCE OF AR IN MILK CONSUMED IN BRAZIL}

The prevalence of subclinical mastitis in Brazilian bovine cattle is high and is frequently associated with the presence of the bacteria Staphylococcus spp and other groups like Streptococcus, Micrococcus, Bacillus and Enterobacter spp (44-46).

Many of these bacteria isolated from animals with mastitis have shown resistance to common antibiotics, which reinforces the concern about the possibility of resistant pathogens and AR being transmitted from animals to humans (13).

Over the past three years, the results of PNCRC to determine AR in Brazilian milk have demonstrated conformity of almost $100 \%$ of the evaluated samples in relation to the MRL set by the Ministry of Health. The results of the 521 samples collected in the years 2010, 2011 and 2012, showed disagreement in only one sample (0.2\%), which was oxytetracycline detected in raw milk at a level corresponding to $981 \mu \mathrm{g} . \mathrm{kg}-1$ $(22,47,48)$

Several authors have analyzed marketed milk for the presence of $A R$ but found no positive results in various regions of the country (49-53).

On the other hand, other researchers have recently reported levels of AR contamination in samples of different types of milk. Oxytetracycline and penicillin $\mathrm{G}$ were the most

\section{TABLE 2}

Results of researches on antibiotic residues in milk marketed in Brazil in the last decade.

\begin{tabular}{|c|c|c|c|c|c|}
\hline Sample & State & Method of detection & $\underset{\mathrm{n}}{\text { Sampling }}$ & $\begin{array}{l}\text { Positive } \\
\text { samples }\end{array}$ & Reference \\
\hline Pasteurized milk & Paraná & Immunoenzymatic & 79 & $19 \%(15)$ & (9) \\
\hline Pasteurized milk & Bahia & HPLC-DAD & 240 & $7.9 \%(19)$ & $(54)$ \\
\hline Pasteurized milk & Paraná & Immunoenzymatic & 260 & $31 \%(80)$ & (10) \\
\hline Pasteurized milk & Rio de Janeiro & Immunoenzymatic & 57 & $65 \%(37)$ & (11) \\
\hline UHT milk & Various & $\begin{array}{l}\text { Microbial inhibition (Streptococcus } \\
\text { thermophilus and Lactobacillus delbrueckii) }\end{array}$ & 100 & $4 \%(4)$ & (23) \\
\hline Different types & Rio de Janeiro & $\begin{array}{l}\text { Microbial inhibition } \\
\text { (B. stearothermophilus) }\end{array}$ & 175 & $1.1 \%(2)$ & (24) \\
\hline Organic raw milk & São Paulo & $\begin{array}{l}\text { Microbial inhibition } \\
\text { (B. stearothermophilus) }\end{array}$ & 148 & $2.7 \%(4)$ & $(25)$ \\
\hline Pasteurized milk & Paraná & Immunoenzymatic & 151 & $2.6 \%(4)$ & (55) \\
\hline Raw milk & Various & $\begin{array}{l}\text { Microbial inhibition } \\
\text { (B. stearothermophilus) }\end{array}$ & 210 & $11.4 \%(24)$ & $(56)$ \\
\hline Different types & São Paulo & $\begin{array}{l}\text { Microbial inhibition } \\
\text { (B. stearothermophilus) }\end{array}$ & 1500 & $0.66 \%(10)$ & (57) \\
\hline Different types & São Paulo & $\begin{array}{l}\text { Microbial inhibition } \\
\text { (E. coli e S.aureus) }\end{array}$ & 100 & $45 \%(45)$ & $(26)$ \\
\hline Raw milk & Various & $\begin{array}{l}\text { Microbial inhibition } \\
\text { (B. stearothermophilus) }\end{array}$ & 209 & $11.5 \%(24)$ & (58) \\
\hline Pasteurized milk & RJ & HPLC-DAD & 43 & $37.21 \%(16)$ & (59) \\
\hline Raw milk & MG & Immunoenzymatic & 158 & $1.89 \%(3)$ & (60) \\
\hline Raw milk & Pará & Immunoenzymatic and microbial inhibition & 103 & $10.68 \%(11)$ & (61) \\
\hline
\end{tabular}


frequent, and these are commonly used for the treatment of bovine mastitis $(9,19)$. Table 2 shows the results of the main studies concerning AR in milk that were published in specialized journals over the last 10 years.

Considering all samples from the studies evaluated in this review ( $n=3,723$ samples) including those without any positive samples, it is estimated that the occurrence of AR contamination in Brazilian milk is approximately $8 \%$. This value indicates that the withdrawal period established after the application of the antibiotics is not being respected.

Korb et al (19) reported that the use of antibiotics to treat diseases of dairy cattle without a prescription from a veterinary professional at small farms is still common. This fact, together with the ease of obtaining these drugs in veterinary stores contributes to aggravate this situation and represents a risk to the consumers.

Another worrying fact is the sale of milk not inspected by federal, state or local bodies, which is still present in Brazilian municipalities. According to Martin (21), the Brazilian surveillance system still lacks efficiency and this author suggested that further discussions on these subjects should be conducted in an attempt to create conditions so that all milk production respects the current regulations in the country.

Concomitant with the trend of increasing awareness of Brazilian dairy farmers about the correct use of antibiotics in dairy cattle, there is a gradual decrease of $M R L$, requiring continuous implementation of quality management programs, especially those intended for milk production.

Also the development of analytical methods that are capable of identifying and quantifying the levels of each antimicrobial in milk are needed. These methodologies, mainly based on chromatographic and spectrometric techniques have been little explored in the current studies, with a predominance of techniques only based on "positivity or absence" of such substances through rapid detection kits. However, these kits do not provide sufficient information for a complete understanding of AR contamination.

Currently in Brazil, there is a tendency to increase the consumption of organic milk, which is free of AR because these drugs can not be used to treat the animals (21). In 2010 the national production of organic milk was about 5.5 million liters, which represents a small portion $(<1 \%)$ of the total sale of Brazilian milk (16). Even so, this milk must be constantly evaluated by the supervisory bodies and researchers for the presence of $A R$, since this contamination has also been reported in a recent study (25).

\section{CONCLUSION}

The incidence of AR contamination in milk consumed and marketed in Brazil is high. The studies published in the last decade indicate that about $8 \%$ of the milk marketed in the country presents levels higher than that permitted by current legislation. Although the Brazilian regulatory limit is considered adequate for the protection of consumers more stringency in audits and the implementation of quality management programs, principally for the awareness and technical training of the dairy producer about the problems resulting from the inappropriate use of antibiotics, are needed. The free sale and distribution of these drugs without a veterinarian prescription should also be discussed by the competent authorities in order to implement better control of these antibiotics. In terms of the various methods to determine $A R$, the use of rapid detection kits based on qualitative results still predominates in the research works carried out in the country. The use of such techniques is important for screening, however, more studies are needed for the development and validation of methodologies based on quantitative techniques, particularly chromatographic and spectrometric, allowing accurate identification and quantification of each antibiotic. Research institutions and universities must be encouraged to produce more studies involving this theme, since only a few reports have been published concerning this theme in scientific journals in recent years.

\section{RESUMEN}

Los antibióticos se utilizan ampliamente para el tratamiento de las vacas lecheras y los residuos de estos medicamentos pueden permanecer en la leche y los productos lácteos, los que pueden ser una amenaza potencial para la salud humana. La exposición a bajos niveles de antibióticos se considera un problema de salud pública ya que pueden resultar en el desarrollo de cepas resistentes de bacterias humanos. De acuerdo con la legislación brasileña, los antimicrobianos deben ser utilizados de acuerdo con las Buenas Prácticas Agrícolas. Sin embargo, estudios recientes han informado de la contaminación de la leche comercializada en el país. Este trabajo tuvo como objetivo revisar los estudios publicados en los últimos 10 años, que describen residuos de antimicrobianos en la leche comercializada en Brasil. Se discuten los límites máximos de residuos, los métodos para la cuantificación y los resultados de los estudios publicados por autores y agencias gubernamentales.

Palabras clave: Antimicrobianos, límite máximo para residuos, seguridad alimentaria. calidad de la leche.

\section{BIBLIOGRAPHY}

1. Embrapa Gado de Leite. Empresa Brasileira de Pesquisa Agropecuária. Principais países produtores de leite no mundo. 2012. Available at: http://www.cnpgl.embrapa. br/ Accessed in April 2013.

2. FDA. US Food and Drug Administration. Center for foof safety and applied nutrition. Hazards \& Controls Guide For Dairy Foods HACCP. CFSAN/Office of Compliance. 2007. Available at: www.fda.gov/ Accessed in April 2013.

3. Trombete FM, Fraga ME, Saldanha T. Contaminação de queijos por Aflatoxina M1: Uma abordagem sobre a ocorrência e prevenção. Rev Inst Latic "Cândido Tostes" 2013, 68: $40-8$.

4. Khaniki GRJ. Chemical Contaminants in milk and public health concerns: A Review. Int J Dairy Sci. 2007, 2: 104-115.

5. FSA. Food Standards Agency. Information and guidance on the testing of milk for antibiotic residues. 2009. Available at: www.food.gov.uk Accessed in April 2013.

6. Battaglini APP, Fagnani $R$, Dunga KS, Beloti V. Difusão de boas práticas e caracterização de propriedades leiteiras. Arch Zootec. 2013, 62: 151-4.

7. Codex Alimentarius. International Food Standards. Veterinary Drug Residues in Food. 2010. Available at: http:// www.codexalimentarius.net/mr/s/vetdrug s/jsp/vetd_q-e. jsp. Accessed in April 2013.

8. MAPA/ACS. Ministério da Agricultura, Pecuária e Abastecimento. Secretaria de Defesa Agropecuária. Análise de resíduos e contaminantes em alimentos. 2011. 32pp. Available at: wWw.agricultura.gov.br/ Accessed in April 2013.

9. Vieira TSWJ, Ribeiro MR, Nunes MP, Machinski Júnior $M$, Netto DP. Detecção de resíduos de antibióticos em amostras de leite pasteurizado do Estado do Paraná, Brasil. Semina 
Ciênc Agrar. 2012, 33: 791-6.

10. Zanella GN, Mikcha JMG, Bando E, Siqueira VLD, Machinski $M$. Occurrence and antibiotic resistance of coliform bacteria and antimicrobial residues in pasteurized cow's milk from Brazil. J Food Prot. 2010, 73: 1684-7.

11. Morais CMQJ, Durães TS, Nóbrega AW, Jacob SC. Presença de resíduos de antibióticos em leite bovino pasteurizado. Food Sci Technol. 2009, 30: 33-5.

12. EFSA. European Food Safety Authority. Fact sheets EFSA explains zoonotic diseases: Antimicrobial Resistance. 2012. Available at: http://www.efsa.europa.eu/ Accessed in April 2013).

13. WHO. World Health Organization. Antimicrobial resistence. Fact Sheet n.194. 2012. Available at: http://www.who. int/mediacentre/factsheets/en/. Accessed in April 2013.

14. EC. European Commission. Communication from the Commission to the European Parliament and the Council. Action plan against the rising threats from Antimicrobial Resistance. Brussels, 17p. 2011.

15. Božo J, Anđel S. Safety and fermentability of dairy products. Food Feed 2011, 68: 77-80.

16. Brasil. Ministerio da Agricultura. Portal Brasil. Cadeia produtiva do leite orgânico. 2011. Available at: http:// www.agricultura.gov.br/ Accessed in April 2013.

17. WHO. World Health Organization. Food and Agriculture Organization of the United Nations. Codex Alimentarius. Milk and Milk Products. 2007.

18. Silva RM, Silva RC, Ribeiro AB. Resíduos de antibióticos em leite. SaBios Rev Saúde Biol. 2012, 7: 30-44.

19. Korb A, Brambilla DK, Teixeira DC, Rodrigues RM. Riscos para a saúde humana do uso de antibióticos na cadeia produtiva leiteira. Rev Saúde Públ. 2011, 4: 21-36.

20. EC. European Commission. Commission regulation No 37/2010 of 22 December 2009 on pharmacologically active substances and their classification regarding maximum residue limits in foodstuffs of animal origin. Official J European Union. 2010.

21. Martin JGP. Resíduos de antimicrobianos em leite - Uma revisão. Seg Alim Nutr. 2011, 18: 80-7.

22. MAPA. Ministério da Agricultura, Pecuária e Abastecimento. Secretaria de Defesa Agropecuária. Instrução Normativa n.6, de 25 de fevereiro de 2011. Resultados do monitoramento do Plano Nacional de Controle de Resíduos e contaminantes 2010. Diário Oficial da União, 28/02/2011. Available at: www.agricultura.gov.br/ Accessed in April 2013.

23. Fonseca GP, Cruz AG, Faria JAF, Silva $R$, Moura MRL, Carvalho LMJ. Antibiotic residues in Brazilian UHT milk: a screening study. Food Sci Technol. 2009, 29: 451-3.

24. Costa AS, Lobato V. Antimicrobianos em leite e bebida láctea UHT por teste de inibição microbiana comercial. Rev Inst Latic "Cândido Tostes" 2009; 64: 72-6.

25. Ribeiro MG, Geraldo JS, Langoni H, Lara GHB, Siqueira AK, Salerno T, Fernandes MC. Microrganismos patogênicos, celularidade e resíduos de antimicrobianos no leite bovino produzido no sistema orgânico. Pesq Vet Bras. 2009, 29:52-8.

26. Biacchi NC, Cardoso AOJ, Ueno M. Detecção de resíduos antibióticos em leite bovino na região do Vale do Paraíba, São Paulo. Rev Biociên. 2004, 10: 47-9.

27. Araújo MMP. Validação de métodos imunoenzimáticos para determinação de resíduos de antimicrobianos no leite. Dissertação (Mestrado em Ciência Animal). Escola de Veterinária, Universidade Federal de Minas Gerais. pp. 462010.
28. Gomes, MF. Avaliação da eficiência de "kits" destinados à detecção de resíduos de antimicrobianos em leite de vacas tratadas com ivermectina e abamectina. Dissertação (Mestrado em Medicina Veterinária). Universidade Federal de Minas Gerais, Escola de Veterinária. 39pp. 2005.

29. Folly MM, Uébe PM, Teixeira GN, Lessa SSA, Carlos LA, Martins MLL. Determinação de resíduos do antibiótico cloxacilina em leite de vacas com elevada contagem de células somáticas. J Bras Ciênc Anim. 2008, 1: 13-24.

30. Feltrin CW, Mello AMS, Santos JGR, Marques MV, Seibel NM, Fontoura LAM. Quantificação de sulfadimetoxina em leite por cromatografia líquida de alta eficiência. Quím Nova 2007, 30: 80-2.

31. Spisso BF, Jesus ALO, Araújo Júnior MAG, Monteiro MA. Validation of a high-performance liquid chromatographic method with fluorescence detection for the simultaneous determination of tetracyclines residues in bovine milk. Anal Chim Acta 2007; 581: 108-17.

32. Rule $R$, Lacchini $R$, Román AG, Antonini A, Buschiazzo P. Influence of feed type on the pharmacokinetics of cephalothin administered to lactating goats. Arch Zootec. 2007, 56: 807-15.

33. Brito RB, Junqueira RG. Determination of beta-lactam residues in milk by High Performance Liquid Chromatography. Braz Arch Biol Technol. 2006; 49: 41-6.

34. Pezza L, Ríos À, Nozal L, Arce L, Valcárcel M. Determinação simultânea de resíduos de cloranfenicol, tianfenicol e florfenicol em leite bovino por cromatografia eletrocinética micelar. Quim Nova 2006, 29: 926-31.

35. Denobile M, Nascimento EDS. Validação de método para determinação de resíduos dos antibióticos oxitetraciclina, tetraciclina, clortetraciclina e doxiciclina em leite por cromatografia líquida de alta eficiência. Rev Bras Cienc Farm. 2004, 40: 209-18.

36. Anastassiades M, Lehotay SJ, Stajnbaher D, Schenck FJ. Fast and easy multiresidue method employing acetonitrile extraction/partitioning and "dispersive solid-phase extraction" for the determination of pesticide residues in produce. J AOAC Int. 2003; 86: 412-31.

37. Heidtmann-Bemvenuti $R$, Hackbart HCS, Souza MM, Badiale-Furlong E, Dors GC, Fagundes CA. Determinação de deoxinivalenol e zearalenona em arroz natural e parboilizado e suas frações utilizando QuEChERS e HPLC/ UV-FL. Quím Nova 2012; 35: 1244-9.

38. Carneiro RP, Oliveira FAS, Madureira FD, Silva G, Souza $W R$, Lopes RP. Development and method validation for determination of 128 pesticides in bananas by modified QUEChERS and UHPLC-MS/MS analysis. Food Control 2013, 33: 413-23.

39. Lopes RP, Reyes RC, Romero-González R, Frenich AG, Vidal $J$ JM. Development and validation of a multiclass method for the determination of veterinary drug residues in chicken by ultra high performance liquid chromatography-tandem mass spectrometry.Talanta 2012, 89: 201-8.

40. Brondi SHG, Souza GB, Nogueira ARA, Camargo LA, Majaron RF. Desenvolvimento e validação do método QuEChERS na determinação de resíduos de medicamentos veterinários em leite e carne de búfalo. Quím Nova 2013, 36: 153-8.

41. Macedo AN. Desenvolvimento de métodos analíticos visando atender aos princípios da química verde na análise de resíduos de medicamentos veterinários em leite bovino. Dissertação (Mestrado em química analítica e inorgânica). Instituto de Química, Universidade de São Paulo. 113 pp. 2012. 
42. INMETRO. Instituto Nacional de Metrologia, Qualidade e Tecnologia. Orientação sobre validação de métodos analíticos. DOQ-CGCRE-008. 20 p. 2010.

43. AOAC. Association of Official Analytical Chemists. Requirements for Single Laboratory Validation of Chemical Methods. 27 pp. 2002.

44. Mota, RA, Medeiros ES, Santos MV, Pinheiro Júnior JW, Moura APBL, Coutinho, LCA. Participação dos Staphylococcus spp na etiologia das mastites em bovinos leiteiros no estado de pernambuco (Brasil). Ci Anim Bras. 2012, 13: 124-30.

45. Parada JL, Gonçalves D, Soccol VT, Lima M, Soccol CR. Bovine mastitis in the metropolitan area of Curitiba: antibiotic resistance and antimicrobial control of the infection. Braz Arch Biol Technol. 2011, 54: 709-16.

46. Oliveira CMC, Sousa MGS, Silva NS, Mendonça $C L$, Silveira JAS, Oaigen RP, Andrade SJT, Barbosa JD. Prevalência e etiologia da mastite bovina na bacia leiteira de Rondon do Pará, estado do Pará. Pesq Vet Bras. 2011; 31: 104-10.

47. MAPA. Ministério da Agricultura, Pecuária e Abastecimento. Secretaria de Defesa Agropecuária. Instrução Normativa n.7, de 04 de abril de 2012. Resultados do monitoramento do Plano Nacional de Controle de Resíduos e contaminantes 2010. Diário Oficial da União, 05/04/2012. Available at: wWw. agricultura.gov.br/ Accessed in April 2013.

48. MAPA. Ministério da Agricultura, Pecuária e Abastecimento. Secretaria de Defesa Agropecuária. Instrução Normativa no7, de 27 de Março de 2013. Resultados do monitoramento do Plano Nacional de Controle de Resíduos e Contaminantes 2012. Available at: www. agricultura.gov. br/ Accessed in April 2013.

49. Carvalho APC, Castro FM, Kawabata CY, Tenório TGS, Vieira EL. Pesquisa de resíduos de antibióticos em amostras de leite cru no município de Araioses - MA. R Trop Ci Agr Biol. 2012, 6: 22-6.

50. Oliveira LP, Barros LSS, Silva VC, Cirqueira MG. Microbiological quality and detection of antibiotic residue in raw and pasteurized milk consumed in the Reconcavo area of the state of Bahia, Brazil. J Food Process Technol. 2012; 3: 1-5.

51. Portz AJ. Avaliação da presença de resíduos de antibióticos e da qualidade microbiológica em leites cru e beneficiado no Distrito Federal. Monografia (Graduação em medicina veterinária). Faculdade de Agronomia e Medicina Veterinária, Universidade de Brasilia. 37pp. 2011.

52. Santos $P A$, Silva $M A P$, Anastácio PIB, Silva Júnior $L C$, Isepon JC, Nicolau ES. Qualidade do leite cru refrigerado estocado por diferentes períodos. Rev Inst Latic "Cândido Tostes" 2008; 364: 36-41.

53. Mendes CG, Sakamoto SM, Silva JBA, Leite Aí. Pesquisa de resíduos de beta-lactâmicos no leite cru comercializado clandestinamente no município de Mossoró, RN, utilizando o DELVOTEST SP. Arq Inst Biol. 2008; 75: 95-8.

54. Magnavita APA. Avaliação das características físico-químicas e da presença de resíduos de antimicrobianos em leite pasteurizado nas regiões sudoeste e sul bahiano. Dissertação (Mestrado em Engenharia de Alimentos). Universidade Estadual do Sudoeste da Bahia, 68 p. 2012.

55. Oliveira RC, Bando É, Machinski Junior M. Ocorrência de cloranfenicol em leite pasteurizado comercializado no estado do Paraná, Brasil. Acta Sci Anim Sci. 2007, 29: 59-62.

56. Nero LA, Mattos MR, Beloti V, Barros MAF, Franco BDGM. Resíduos de antibióticos em leite cru de quatro regiões leiteiras no Brasil. Food Sci Technol. 2007, 27: 391-3.

57. Leme FBP. Presença de resíduos de antimicrobianos em amostras de diferentes tipos de leite comercializados no município de São Paulo. Dissertação (Mestrado em Epidemiologia Experimental e Aplicada às Zoonoses) - Universidade de São Paulo, 105pp. 2005.

58. Nero $L A$, Mattos $M R$, Beloti $V$, Barros MAF, Netto DP, Pinto JPAN, Andrade NJ, Silva WP, Franco BDFM. Hazards in non-pasteurized milk on retail sale in Brazil: prevalence of Salmonella spp, Listeria monocytogenes and chemical residues. Braz J Microbiol. 2004, 35: 211-5.

59. Carlos LA, Cordeiro CAM, Folly MM, Martins MLL. Avaliação físico-química, microbiológica e de resíduos de penicilina, em leite tipo " $C$ " comercializado no município de Campos dos Goytacazes, RJ. Hig Aliment. 2004; 18: 57-61.

60. Almeida $L P$, Vieira $R L$, Rossi DA, Carneiro AL, Rocha $M L$. Resíduos de antibióticos em leite de propriedades rurais da região de Uberlândia-MG. Biosci J. 2003; 19: 83-7.

61. Macedo LCS, Freitas JA. Ocorrência de resíduos de antimicrobianos em leite. Rev Ciênc Agrár. 2009, 1: 147-57. 